\title{
STUDI HUBUNGAN ANTARA PERHATIAN ORANG TUA DAN MOTIVASI TERHADAP PRESTASI BELAJAR SISWA DI MAN 2 PIDIE KECAMATAN MUTIARA KABUPATEN PIDIE
}

\section{STUDY OF RELATIONSHIP BETWEEN PARENTS 'ATTENTION AND MOTIVATION OF STUDENT LEARNING ACHIEVEMENT IN MAN 2 PIDIE KECAMATAN MUTIARA DISTRICT PIDIE}

\author{
Heri Fajri' ${ }^{1}$, Riska ${ }^{2}$ \\ ${ }^{1,2}$ Fakultas Keguruan dan Ilmu Pendidikan Universitas Jabal Ghafur
}

E-mail: herifajriunigha@gmail.com

Diterima: 11/03/2020; Disetujui: 31/03/2020

\begin{abstract}
ABSTRAK
Penelitian ini bertujuan mengetahui hubungan antara perhatian orang tua dan motivasi terhadap prestasi belajar siswa di MAN 2 Pidie Kecamatan Mutiara Kabupaten Pidie. Penelitian ini merupakan penelitian ex-post facto dengan pendekatan kuantitatif. Populasi penelitian ini adalah seluruh siswa dengan sampel yang diambil sejumlah 75 siswa. Pengumpulan data dilakukan melalui angket dan nilai rapor. Teknik analisis data yang digunakan adalah korelasi sederhana dan korelasi ganda. Berdasarkan hasil penelitian dihasilkan bahwa terdapat hubungan positif dan signifikan antara perhatian orang tua dengan prestasi belajar siswa ditunjukkan dengan nilai $r_{x 1 y}$ sebesar 0,72 dan $t_{\text {hitung }}$ lebih besar dari $t_{\text {tabel }}$ pada signifikan $5 \% \quad 0,576>1,998$; (2) terdapat hubungan positif dan signifikan antara motivasi dengan prestasi belajar siswa dengan nilai $r_{x 2 y}$ sebesar 0,77 dan $t_{\text {hitung }}$ lebih besar dari $t_{\text {tabel }} 614>1,998$; dan (3) terdapat hubungan positif dan signifikan antara perhatian orang tua dan motivasi secara bersama-sama terhadap prestasi belajar siswa dengan nilai $r_{y(1,2)}$ sebesar 0,112 dan $F_{\text {hitung }}$ lebih besar dari $F_{\text {tabel }}$ sebesar 3,92 > 3,15.
\end{abstract}

Kata kunci: Perhatian Orang Tua, Motivasi, Prestasi Belajar. 


\begin{abstract}
This study aims to find out the relationship between parents' attention and motivation on student achievement in MAN 2 Pidie, Mutiara District, Pidie Regency. This research is an ex-post facto research with a quantitative approach. The population of this research is all students of MAN 2 Pidie, Mutiara District, Pidie Regency by taking a sample of 75 students. Data collection is done through a questionnaire and report card grades. Data analysis techniques used are simple correlation and multiple correlation. The result of study is a positive and significant relationship between the attention of parents with student learning achievement with indicated by a r_x1y value of 0.72 and tcount is greater than ttable at a significant 5\% 0.576> 1,998; significant relationship between motivation and student with a value of $r_{-} x 2 y$ of 0.77 and tcount is greater than ttable 614> 1.998; and relationship between parents 'attention and motivation together with students' learning with a value of $r_{-}$(y (1.2)) of 0.112 and $F_{-}$count is greater than $F_{-}$table for 3.92> 3.15.
\end{abstract}

Keywords: Parental Attention, Motivation, Learning Achievement.

\title{
PENDAHULUAN
}

Keluarga mempunyai peranan penting dan tanggung jawab utama atas perawatan dan perlindungan anak sejak bayi hingga remaja. Sebuah keluarga, tempat tumbuh anaknya, merupakan sumber pendidikan pertama kali bagi akal sang anak, sebagaimana keluarga juga menjadi tempat pertama kali seorang anak mendapat banyak pengaruh dari pengetahuan yang merebak di masyarakat. Pentingnya peran keluarga terlihat jelas pada fase pertama dalam kehidupan sang anak. Karena perkembangan pada masa awal kanak-kanak, menjadi pondasi perkembangan anak pada masa-masa selanjutnya (Musthafa 2015:38).

Keluarga merupakan lembaga sosial yang paling kecil yang terdiri atas ayah, ibu, dan anak. Anak pada lingkungan sosial ini (keluarga) mampu mengenali dan membentuk dirinya melalui interaksi yang terjadi antara dia bersama anggota keluarga yang hidup bersamanya. Dari beberapa fungsi keluarga salah satunya adalah memberikan pendidikan yang terbaik yakni pendidikan yang mencakup pengembangan potensi-potensi yang dimiliki oleh anak-anak, yaitu: potensi fisik, potensi nalar, dan potensi nurani/qalbu.

Dengan pendidikan yang utuh tersebut akan mengembangkan kualitas kepribadian anak dan mampu mengatualisasikan potensi-potensi dirinya secara menyeluruh. Dan kualitas sumberdaya manusia (SDM) yang dibutuhkan sekarang dan masa datang, yakni kualitas sumber daya manusia yang meliputi; kreatifitas yang kuat, produktifitas yang tinggi, kepribadian yang tangguh, kesadaran sosial 
yang besar, keimanan dan ketaqwaan kepada Tuhan Yang Maha Esa.

Siswa Sekolah Menengah Atas (SMA) sebagai salah satu unsur sumberdaya manusia yang potensi sangat diperlukan dalam rangka mencapai kemajuan bangsa, "Di indonesia, pendidikan diarahkan pada pembentukan manusia indonesia seutuhnya sebagai warga negara yang pacasila”. Pada dasarnya, proses pendidikan dapat terjadi dalam banyak situasi sosial yang menjadi ruang lingkup kehidupan manusia. Secara garis besar proses pendidikan dapat terjadi dalam tiga lingkungan pendidikan yang terkenal dengan sebutan : TriLogi Pendidikan, yaitu pendidikan di dalam keluarga (Pendidikan informal), Pendidikan di dalam Sekolah (Pendidikan Formal), dan Pendidikan didalam Masyarakat (Pendidikan Non formal).

Pendidikan dalam keluarga merupakan pendidikan kodrati. Setelah anak lahir orang pertama kali dikenal adalah orang tua yang memberi rasa cinta kasih, ketentraman dan kedamaian. Anak-anak akan tumbuh dalam lingkungan keluarganya dengan segala sikap tingkah laku orang tuanya yang sangat mempengaruhui perkembangan anaknya, karena ayah ibu adalah lembaga pendindikan pertama dalam kehidupan yang di ikuti oleh anak yang akan mempengaruhi pendidikan selanjutnya.

Komunikasi sangat penting dalam keluarga, karena komunikasi orang tua dengan anak memegang peranan penting dalam membina hubungan keduanya. Misalnya dalam keluarga anak butuh bimbingan dari orang tuanya dalam melakukan sesuatu hal dan orang tua juga harus menbantu dalam mengarah kan sianak. Orang tua yang kurang berkomunikasi dengan anak akan menimbulkan kerenggangan atau komplik hubungan, maka dari itu orang tua dan anak harus memiliki komunikasi yang sangat erat antara keduanya.

Pendidikan formal pada umumnya tidaklah mudah. Karena disepanjangan tahun khususnya pada tahun ajaran baru, mutu pendidikan yang berkaitan dengan pencapain tujuan pendidikan secara umun disegala jenjang pendidikan formal, termasuk SMA sering dipermasalahkan. Permasalahan yang seringkali terjadi lebih cenderung terhadap motivasi dan prestasi belajar yang dicapai siswa. Faktorfaktor yang mempengaruhi prestasi belajar siswa tentunya beraneka ragam, tetapi secara garis besar ada dua faktor yaitu faktor-faktor pada pihak siswa dan faktor-faktor diluar siswa. Prestasi belajar menjadi sebuah motivasi belajar bagi siswa yang ingin mencapai prestasi belajar yang baik.

Motivasi merupakan dorongan untuk belajar yang timbul pada individu berasal dari diri individu, orang tua, guru juga adanya pengaruh perhatian orang tua. Karena hasil belajar yang baik dipengaruhi oleh motivasi dalam belajar, perhatian orang tua, maka keduanya menjadi perlu untuk dibahas dan 
diteliti. Uruain tersebut diatas mendorong penulis untuk mengadakan penelitian lebih lanjut tentang "Hubungan Antara Perhatian Orang tua dan Motivasi terhadap Prestasi Belajar siswa di MAN 2 Pidie Kecamatan Mutiara'.

\section{Perhatian Orang Tua}

Perhatian merupakan kegiatan yang dilakukan seseorang dalam hubungannya dengan pemilihan rangsangan yang datang dari lingkungannya. Perhatian sangat dipengaruhi oleh perasaan dan suasana hati, serta ditentukan oleh kemauan. Perhatian juga dapat diartikan sebagai peningkatan aktivitas mental terhadap suatu rangsangan tertentu, Perhatian dapat lebih memusatkan pengamatan individu kepada suatu rangsangan, sehingga pengamatan menjadi lebih efektif. Perhatian merupakan aspek perilaku yang mempunyai peranan penting dalam proses pembelajaran. Dalam aktivitas pembelajaran guru harus mengusahakan agar siswa dapat melakukan pengamatan yang efektif agar memperoleh hasil pembelajaran yang sebaikbaiknya. Perhatian, merupakan salah satu bentuk perilaku kognitif, yaitu proses mengenal lingkungan dengan menggunakan alat indera.

Menurut Walgito (2002: 78) "Perhatian merupakan pemusatan atau konsentrasi dari seluruh aktivitas yang ditunjukkan pada suatu kelompok atau objek." Sedangkan menurut Dakir (1993:114) "Perhatian adalah keaktifan peningkatan kesadaran seluruh fungsi jiwa yang dikerahkan dalam pemusatannya kepada barang sesuatu baik yang ada di dalam maupun yang ada di luar individu".

Perhatian orang tua adalah pemusatan energi psikis yang tertuju pada suatu objek yang dilakukan oleh ayah dan ibu atau wali terhadap anaknya dalam suatu aktivitas, pemenuhan kebutuhan fisik psikis dan fasilitas belajar, penciptaan suasana yang baik dalam keluarga, pemberian motivasi serta pengawasan, yang diberikan oleh bapak dan ibu dalam keluarga.

\section{Motivasi Belajar}

Menurut Ruswandi (2013:134) Motivasi dapat diartikan sebagai suatu upaya untuk menimbulkan atau meningkatkan dorongan dalam upaya mewujudkan perilaku yang terarah kepada pencapaian suatu tujuan. Motivasi belajar yaitu berbagai upaya, kekuatankekuatan, atau tenaga-tenaga yang dapat memberikan dorongan yang dilakukan siswa dalam proses perkembangannya yang meliputi maksud, kemauan, kehendak. Semangat. Gairah, atau cita-cita untuk melaksanakan kegiatan belajar dalam rangka mencapai tujuan. Motivasi merupakan kekuatan atau energi seseorang yang dapat menimbulkan tingkat persistensi dan entusiasmenya dalam melaksanakan suatu kegiatan. Kajian motivasi telah sejak lama memiliki daya tarik tersendiri bagi berbagai kalangan, termasuk guru dan siswa, terutama dikaitkan dengan kepentingan upaya pencapaian prestasi mengajar atau prestasi belajar. 
Menurut Sardiman (2011:75) motivasi belajar merupakan keseluruhan daya penggerak di dalam diri peserta didik yang menimbulkan kegiatan belajar, yang menjamin kelangsungan dari kegiatan belajar dan yang memberikan arah pada kegiatan belajar sehingga tujuan yang di kehendaki oleh subjek belajar itu dapat tercapai.

\section{Prestasi Belajar}

Menurut Arikunto (2010: 276) "prestasi harus mencerminkan tingkatan-tingkatan sejauh mana telah dapat mencapai tujuan yang telah di tetapkan disetiap bidang studi”. Sedangkan menurut Arifin (2012: 12) Prestasi diartikan sebagai "hasil usaha". Prestasi dapat dikatakan sebagai hasil dari pengukuran dan penilaian suatu usaha, usaha dalam hal ini adalah usaha belajar. Dengan mengetahui prestasi belajar, dapat diketahui kedudukan anak di dalam kelas. Jadi dapat disimpulkan bahwa prestasi merupakan hasil akhir usaha yang di capai yang mencerminkan tingkatan-tingkatan sejauh mana telah dapat mencapai tingkat keberhasilan yang ditetapkan.

\section{METODE PENELITIAN}

Penelitian ini menggunakan metode Kuantitatif dengan menggunakan pendekatan metode ex post facto. Ex post facto secara harfiah berarti "sesudah fakta", karena kausa atau sebab yang diselidiki tersebut sudah berpengaruh terhadap variabel lain (Rangkuti 2014:80). Penelitian ex post facto merupakan penelitian yang bertujuan menemukan penyebab yang memungkinkan perubahan perilaku, gejala atau fenomena yang disebabkan oleh suatu peristiwa, perilaku atau hal-hal yang menyebabkan perubahan pada variabel bebas yang secara keseluruhan sudah terjadi. Menurut Sukardi (2013:165) metode ex post facto merupakan penelitian dimana variabel-variabel bebas telah terjadi ketika peneliti mulai dengan pengamatan variabel terikat dalam suatu penelitian

Adapun Lokasi penelitian pada MAN 2 Pidie Kecamatan Mutiara, Kabupaten Pidie, yang menjadi subjek penelitian ini adalah Kepala Sekolah dan Guru pada MAS 17 Bambong, Kabupaten Pidie. Populasi dalam penelitian ini adalah siswa yang ada di MAN 2 Pidie Kecamatan Mutiara, jumlah siswa yang ada di MAN 2 Pidie sebanyak 500 siswa, yang terdiri dari 15 kelas dari kelas X sampai kelas XII. Dari jumlah siswa tersebut dalam penelitian ini mengambil sampel 75 siswa yang terdiri dari kelas XI IIS.

Pengambilan sampel dalam penelitian menggunakan tabel penentuan jumlah sampel dari populasi tertentu yang dikembangkan oleh Issac dan Michael, meliputi tingkat kesalahan $1 \%$, 5\%, dan 10\%. Berdasarkan tabel tersebut dapat ditarik kesimpulan bahwa semakin besar tingkat kesalahan, maka semakin kecil ukuran sampel dengan asumsi populasi berdistribusi normal. Dengan menggunakan tabel Issac dan Michael tersebut diperoleh jumlah sampel 65 
siswa dari jumlah 75 siswa, dimana tingkat kesalahan yang dikehendaki adalah 5\%. Dari siswa dari kelas XI IIS 1, XI IIS 2, dan XI IIS 3.

Teknik pengambilan sampel dalam penelitian ini menggunakan Stratified random sampling, yaitu dengan cara sampel diambil dari populasi yang terlebih dahulu dan kemudian dikelompokkan dalam sub-populasi yang terdapat didalam populasi, yang menjadi sub populasi dalam penelitian ini meliputi siswa kelas XI IIS. kemudian sampel di ambil secara acak dari setiap sub-populasi, setiap sub populasi berpeluang menjadi anggota sampel oleh karena itu tidak semua anggota populasi terpilih menjadi anggota sampel.

Instrumen penelitian digunakan untuk mengukur nilai variabel yang diteliti menggunakan angket untuk memperoleh data dari responden mengenai Perhatian Orang Tua dan Motivasi sedangkan untuk Prestasi Belajar menggunakan rapor. Pada penelitian ini menngunakan dua Variabel yaitu Perhatian Orang Tua dan Motivasi dengan menggunakan instrumen angket dengan menggunakan skala Likert dari skor 1 sampai 4 pada setiap pernyataan.

Untuk mengetahui baik atau tidaknya instrumen yang akan digunakan maka terlebih dahulu instrumen tersebut diujicobakan. Uji coba instumen dilakukan di Sekolah yang berbeda. Dalam pengujian istrumen ini akan dilakukan dua pengujian yaitu uji validitas dan uji reliabilitas.
Teknik Analisis data yang digunakan dalam penelitian ini meliputi proses menyelidiki, menyederhanakan, memfokuskan, mengabstraksikan, mengorganisasikan data secara sistematis dan rasional sesuai dengan tujuan penelitian, serta mendeskripsikan data hasil penelitian itu dengan menggunakan tabel sebagai alat bantu untuk memudahkan dalam menginterpretasikan. Kemudian data hasil penelitian pada masing-masing tabel tersebut di interpretasikan (pengambilan makna) dalam bentuk naratif (uraiaan) dan dilakukan penyimpulan. pengolahan data menggunakan SPSS melalui langkah-langkah melakukan uji Analisis statistik deskriptif, Uji Normalitas, dan pengujian Hipotesis

\section{HASIL PENELITIAN DAN PEMBAHASAN}

\section{Statistik Deskriptif}

Pada bagian ini menyajikan data deskriptif dari masing-masing variabel berdasarkan data yang diperoleh di lapangan yaitu sebanyak 65 responden. Deskripsi data yang disajikan masing-masing variabel meliputi nilai mean, median, modus, dan standar deviasi yang digunakan untuk mendeskripsikan data dari variabel bebas yaitu Perhatian Orang Tua (X1) dan Motivasi (X2), dan variabel terikat yaitu Prestasi Belajar (Y).

\section{a. Variabel Perhatian Orang Tua (X1) \\ Data variabel Perhatian Orang Tua (X1)} diperoleh dari angket (kuesioner) yang di isi oleh 65 peserta didik kelas XII IIS MAN 2 Pidie. Angket tersebut terdiri dari 24 butir 
pertanyaan dengan 4 alternatif jawab yaitu Sering (SR), Selalu (SL), Kadang-kadang (KK), Tidak Pernah (TP). Skor yang digunakan untuk butir pernyataan positif adalah 4, 3, 2 dan 1 dan untuk butir pernyataan yang negatif adalah 1, 2, 3, dan 4.Berdasarkan data variabel Perhatian Orang Tua yang diolah menggunakan bantuan program IBM SPSS Statistics20, perhitungan statistik diperoleh hasil skor terendah sebesar 47dan skor tertinggi 88 sedangkan nilai Mean (M) sebesar 69,63, Median (Me) sebesar, 69,00, Modus (MO) sebesar 65 dan Standar Deviasi sebesar 6,839.

Tabel distribusi frekuensi variabel Perhatian Orang Tua disajikan dengan langkahlangkah sebagai berikut:

1) Menghitung jumlah kelas interval

$$
\begin{aligned}
\mathrm{K} & =1+3,3 \log \mathrm{n} \\
& =1+3,3 \log 65 \\
& =1+3,3(1.81291336) \\
& =6.98261409 \text { dibulat kan } 7 \\
& \text { 2) Menghitung retang kelas (range) }
\end{aligned}
$$

Skor maksimal - skor Minimal $=88-47$

$$
=41
$$

3) Menentukan panjang kelas interval $\frac{\text { rentangkelas }+1}{\text { jumlahkelasinterval }}=\frac{41+1}{7}=6$

Tabel distribusi frekuensi variabel Perhatian Orang Tua adalah sebagai berikut: Tabel 6 .Distribusi Frekuensi perhatian orang Tua

\begin{tabular}{|l|l|l|l|}
\hline NO. & Interval & Frekuensi & Frekuensi \\
\hline
\end{tabular}

\begin{tabular}{|r|r|r|c|}
\hline & & & $(\%)$ \\
\hline 1 & $47-53$ & 2 & $3,0 \%$ \\
\hline 2 & $54-59$ & 1 & $1,5 \%$ \\
\hline 3 & $60-65$ & 14 & $21,5 \%$ \\
\hline 4 & $66-71$ & 28 & $43,0 \%$ \\
\hline 5 & $72-77$ & 14 & $21,5 \%$ \\
\hline 6 & $78-83$ & 5 & $8,7 \%$ \\
\hline 7 & $84-88$ & 2 & $3,0 \%$ \\
\hline & Jumlah & 65 & $100 \%$ \\
\hline
\end{tabular}

Berdasarkan tabel distribusi frekuensi tersebut Perhatian Orang tua di atas, maka histrogram data Perhatian Orang Tua sebagai berikut:

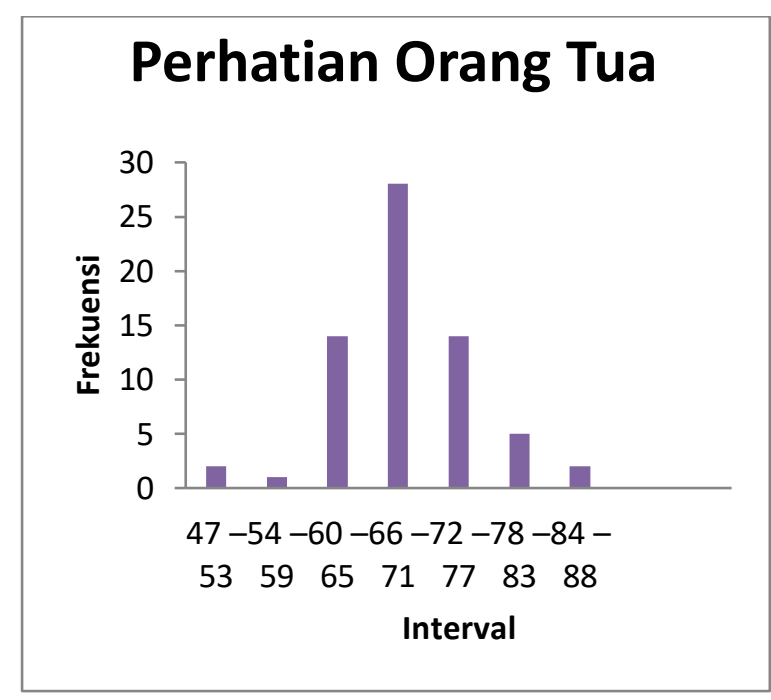

Gambar 1. Histogram Distribusi Frekuensi Variabel Perhatian Orang tua

Setelah diperoleh distribusi frekuensi dan dibuat histogram, selanjutnya di indentifikasi kecenderungan variabel Perhatian 
Orang Tua. Kecenderungan variabel Perhatian Orang Tua dikeahui dengan menghitung harga Mean ideal (Mi) dan StandarDeviasi ideal (Sdi). Berdasarkan data tersebut, diperoleh skor teringgi ideal adalah 4 × $24=96$ dan skor terendah ideal adalah $1 \times 24=24$

Mean ideal (Mi) dan Standar Deviasi ideal (SDi) variabel Perhatian Orang Tua dihitung dengan rumus sebagai berikut:

Mean ideal $=\frac{1}{2}($ skor tertinggi + skor terendah)

$$
\begin{aligned}
& =\frac{1}{2}(96+24) \\
& =60
\end{aligned}
$$

Standar Deviasi $=\frac{1}{6}$ (skor tertinggi

- skor terendah)

$$
\begin{aligned}
& =\frac{1}{6}(96-24) \\
& =12
\end{aligned}
$$

$$
\begin{aligned}
\text { Rendah } & =<(\mathrm{Mi}-1 . \mathrm{SDi}) \\
& =<(60-12) \\
& =<48 \\
\text { Sedang } & =(\mathrm{Mi}-1 . \mathrm{SDi}) \\
(\mathrm{Mi}+1 . \mathrm{SDi}) & =(60-12)-(60 \\
12) & =48-72 \\
& =>(\mathrm{Mi}+1 . \mathrm{SDi}) \\
\text { Tinggi } & =>(60+12) \\
& =>72
\end{aligned}
$$

\begin{tabular}{|c|c|c|c|c|c|c|}
\hline No. & $\begin{array}{l}\text { Kecende } \\
\text { rungan }\end{array}$ & $\begin{array}{c}\text { Sko } \\
\text { r }\end{array}$ & $\begin{array}{c}\text { Freku } \\
\text { ensi }\end{array}$ & $\begin{array}{c}\text { Presen } \\
\text { tase }\end{array}$ & $\begin{array}{c}\text { Katego } \\
\text { ri }\end{array}$ & \\
\hline 1 & $\begin{array}{l}<(\mathrm{Mi}- \\
\text { 1. SDi })\end{array}$ & $<48$ & 1 & $1,5 \%$ & Rendah & $\begin{array}{l}\text { Gambar 2. Pie Char } \\
\text { Kecenderungan varia }\end{array}$ \\
\hline 2 & $\begin{array}{l}\mathrm{Mi}- \\
\text { 1.SDi) } \\
\text { sampai }\end{array}$ & $\begin{array}{c}48- \\
72\end{array}$ & 44 & $67,7 \%$ & Sedang $b$. & Variabel Motivasi \\
\hline
\end{tabular}

Berdasarkan perhitungan tersebut, maka diperoleh kecenderungan $X_{1}$, sebagai berikut:

Tabel 7 . Kategori Frekuensi

Kecenderungan Perhatian Orang Tua ini:

Berdasarkan tabel diatas, variabel Perhatian Orang Tua menunjukkan terdapat 1 peserta didik $(1,5 \%)$ termasuk kategori Rendah, 44 peserta didik $(67,7 \%)$ termasuk kategori Sedang dan 20 peserta $\operatorname{didik}(30,8 \%)$ termasuk kedalam kategori Tinggi. Data tersebut menunjukkan kecenderungan Perhatian Orang Tua peserta didik kelas XI IPS MAN 2 Pidie terletak pada kategori sedang

Berdasarkan tabel kategori frekuensi kecenderungan variabel Perhatian orang tua diatas, maka dibuat pie chart distribusi frekuensi kecenderungan variabel Perhatian Orang Tua yang disajikan dalam gambar berikut

\section{perhatian orang tua}

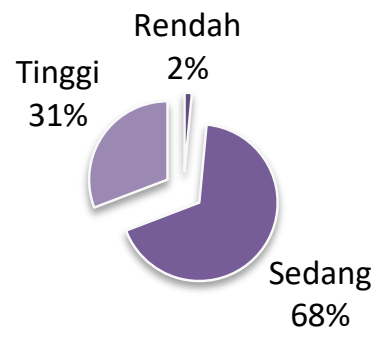


Data variabel Motivasi (X2) diperoleh dari angket (kuesioner) yang di isi oleh 65 peserta didik kelas XII IIS MAN 2 Pidie. Angket tersebut terdiri dari 26 butir pertanyaan dengan 4 alternatif jawab yaitu Sering (SR), Selalu (SL), Kadang-kadang (KK), Tidak Pernah (TP). Skor positif yang digunakan 4, 3, 2 dan 1 dan untuk skor negatif $1,2,3$, dan 4 sehingga bisa di peroleh skor tertinggi 104 (26 X 4) dan skor terendah 26 (26 X 1). Berdasarkan data variabel motivasi yang diolah menggunakan bantuan program IBM SPSS Statistics 20, perhitungan statistik diperoleh hasil skor terendah sebesar 62 dan skor tertinggi 85 sedangkan nilai Mean (M) sebesar 70,45, Median (Me) sebesar 70,00, Modus (MO) sebesar 67 dan Standar Deviasi sebesar 5,016

Tabel distribusi frekuensi variabel Perhatian Orang Tua disajikan dengan langkah-langkah sebagai berikut:

1. Menghitung jumlah kelas interval $\mathrm{K}=1+3,3 \log \mathrm{n}$

$$
\begin{aligned}
& =1+3,3 \log 65 \\
& =1+3,3(1.81291336) \\
& =6.98261409 \text { dibulat kan } 6
\end{aligned}
$$

2. Menghitung retang kelas (range)

Skor maksimal - skor Minimal $=85-62$

$$
=23
$$

3. Menentukan panjang kelas interval $\frac{\text { rentangkelas }+1}{\text { jumlahkelasinterval }}=\frac{23+1}{6}=4$
Tabel distribusi frekuensi variabel Motivasi adalah sebagai berikut:

Tabel 8. Distribusi Frekuensi Motivasi

\begin{tabular}{|r|r|r|r|}
\hline NO. & Interval & Frekuensi & $\begin{array}{r}\text { Frekuensi } \\
(\%)\end{array}$ \\
\hline 1 & $62-65$ & 9 & $13,8 \%$ \\
\hline 2 & $66-69$ & 23 & $35,3 \%$ \\
\hline 3 & $70-73$ & 18 & $27,7 \%$ \\
\hline 4 & $74-77$ & 8 & $12,3 \%$ \\
\hline 5 & $78-81$ & 4 & $6,1 \%$ \\
\hline 6 & $82-85$ & 3 & $4,6 \%$ \\
\hline & Jumlah & 65 & $100 \%$ \\
\hline
\end{tabular}

Berdasarkan tabel distribusi frekuensi Motivasi di atas, maka histrogram data Motivasi adalah :

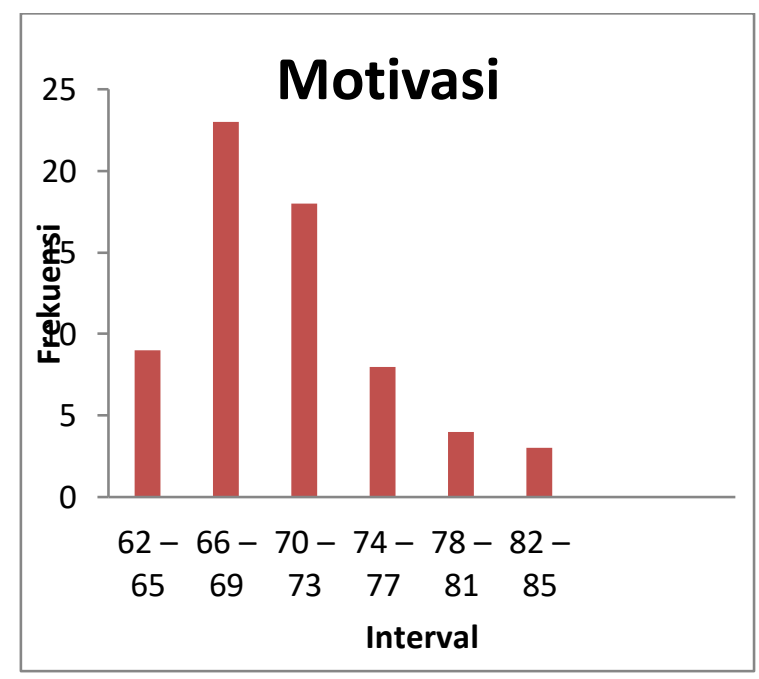

Gambar 3. Histogram Distribusi Frekuensi Variabel Motivasi 
Setelah diperoleh distribusi frekuensi dan dibuat histogram, selanjutnya di indentifikasi kecenderungan variabel Motivasi. Kecenderungan variabel Motivasi diketahui dengan menghitung harga Mean ideal (Mi) dan Standar Deviasi ideal (Sdi). Berdasarkan data tersebut, diperoleh skor teringgi ideal adalah $4 \mathrm{x}$ $26=104$ dan skor terendah ideal adalah $1 \times 26$ $=26$

Mean ideal (Mi) dan Standar Deviasi ideal (SDi) variabel Motivasi dihitung dengan rumus sebagai berikut:

Mean ideal $\quad=\frac{1}{2}($ skor tertinggi + skor terendah)

$$
\begin{aligned}
& =\frac{1}{2}(104+26) \\
& =65
\end{aligned}
$$

Standar Deviasi $=\frac{1}{6}$ (skor tertinggi - skor terendah)

$$
\begin{aligned}
& =\frac{1}{6}(104-26) \\
& =13
\end{aligned}
$$

$$
\begin{aligned}
\text { Rendah } & =<(\mathrm{Mi}-1 . \mathrm{SDi}) \\
& =<(65-13) \\
& =<52 \\
\text { Sedang } & =(\mathrm{Mi}-1 . \mathrm{SDi})- \\
(\mathrm{Mi}+1 . \mathrm{SDi}) & =(65-13)-(65 \\
+13) \quad & =52-78 \\
& =>(\mathrm{Mi}+1 . \mathrm{SDi}) \\
\text { Tinggi } & =>(65+13) \\
& =78
\end{aligned}
$$

Berdasarkan perhitungan tersebut, maka diperoleh kecenderungan $X_{2}$, sebagai berikut:

Tabel 9. Kategori Frekuensi Kecenderungan

Motivasi

\begin{tabular}{|c|c|c|c|c|c|}
\hline $\begin{array}{c}\text { N } \\
\text { o. }\end{array}$ & $\begin{array}{c}\text { Kecender } \\
\text { ungan }\end{array}$ & $\begin{array}{c}\text { Sk } \\
\text { or }\end{array}$ & $\begin{array}{c}\text { Freku } \\
\text { ensi }\end{array}$ & $\begin{array}{c}\text { Presen } \\
\text { tase }\end{array}$ & $\begin{array}{c}\text { Kate } \\
\text { gori }\end{array}$ \\
\hline 1 & $<(\mathrm{Mi}-1$. & $<$ & 0 & 0 & Rend \\
& SDi $)$ & 52 & & & ah \\
\hline
\end{tabular}

\begin{tabular}{|c|c|c|c|c|c|}
\hline 2 & $(\mathrm{Mi}-$ & 52 & 59 & $90,8 \%$ & Sedan \\
& $1 . \mathrm{SDi})$ & - & & & $\mathrm{g}$ \\
& sampai & 78 & & & \\
& $(\mathrm{Mi}+$ & & & & \\
& $1 . \mathrm{SDi})$ & & & & \\
\hline 3 & $>(\mathrm{Mi}+$ & $>$ & 6 & $9,2 \%$ & Tingg \\
& $1 . \mathrm{SDi})$ & 78 & & & $\mathrm{i}$ \\
\hline \multicolumn{2}{|r|}{ Jumlah } & & 65 & $100 \%$ & \\
\hline
\end{tabular}

Berdasarkan tabel diatas, variabel Motivasi menunjukkan terdapat 0 peserta didik termasuk kategori Rendah, 59 peserta didik ( 90,8\%) termasuk kategori Sedang, dan 6 peserta $\operatorname{didik}(9,2 \%)$ termasuk kedalam kategori Tinggi. Data tersebut menunjukkan kecenderungan Motivasi peserta didik kelas XI IPS Man 2 Pidie terletak pada kategori sedang. Berdasarkan tabel kategori frekuensi kecenderungan variabel Motivasi diatas, maka dibuat pie chart distribusi frekuensi kecenderungan variabel Motivasi yang disajikan dalam gambar berikut ini:

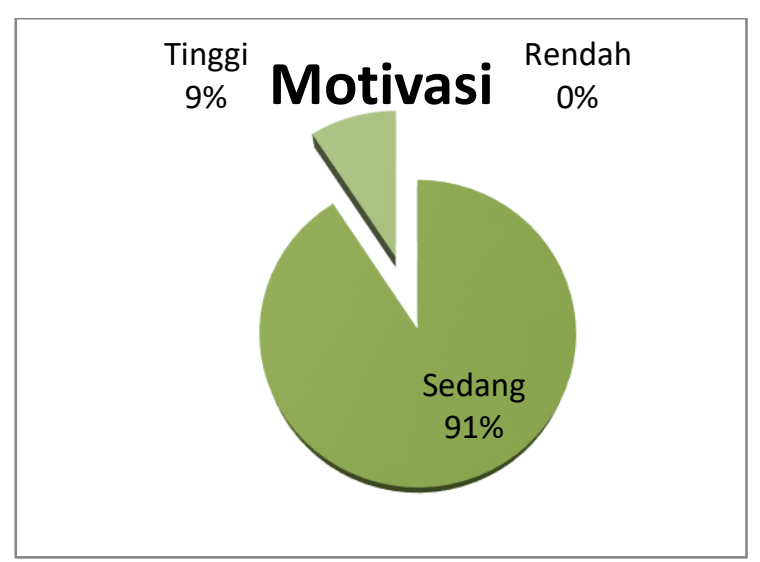

Gambar 4. Pie Chart Distribusi Frekuensi Kecenderungan Variabel Motivasi

c. Variabel Prestasi Belajar (Y) 
Data tentang Prestasi Belajar siswa dalam peneliian ini diperoleh dari hasil ujian tengah semester kelas XI MAN 2 Pidie tahun ajaran 2018 sebanyak 65 peserta didik. Berdasarkan data variabel Prestasi Belajar yang diolah menggunakan IBM SPSS Statistics 20, diperoleh skor tertinggi adalah 90,00, dan skor terendah 75,33. Hasil analisis menunjukkan rerata (mean) sebesar 81,8451, median 80,5500, modus 80,00 dan standar deviasi 4,03726.

Tabel distribusi frekuensi variabel Prestasi Belajar disajikan dengan langkah-langkah sebagai berikut:

1). Menghitung jumlah kelas interval

$$
\begin{aligned}
\mathrm{K}=1+3,3 \log \mathrm{n} & \\
& =1+3,3 \log 65 \\
& =1+3,3(1.81291336) \\
& =6.98261409 \text { dibulat kan } 7
\end{aligned}
$$

2). Menghitung retang kelas (range)

Skor maksimal - skor Minimal $=90,00-$

$$
\begin{aligned}
& 75,33 \\
= & 14,67
\end{aligned}
$$

3). Menentukan panjang kelas interval

$$
\begin{aligned}
& \frac{\text { rentangkelas }+1}{\text { jumlahkelasinterval }}=\frac{14,67+1}{7} \\
& =2.23 \text { dibulatkan menjadi } 2.2
\end{aligned}
$$

Tabel distribusi frekuensi variabel Prestasi Belajar adalah sebagai berikut:

Tabel 10. Distribusi Frekuensi Variabel Prestasi

$$
\text { Belajar }
$$

\begin{tabular}{|r|l|l|c|}
\hline NO. & Interval & Frekuensi & $\begin{array}{c}\text { Frekuensi } \\
(\%)\end{array}$ \\
\hline 1 & $5,33-75,76$ & 6 & $9,2 \%$ \\
\hline 2 & $5,87-75,90$ & 4 & $6,1 \%$ \\
\hline 3 & $0.00-80,55$ & 24 & $36,9 \%$ \\
\hline & $0,77-80,89$ & 7 & $10,7 \%$ \\
\hline 5 & $5,00-85,67$ & 13 & $20 \%$ \\
\hline 6 & $5,76-85,95$ & 4 & $6,1 \%$ \\
\hline 7 & $5,98-90.00$ & 7 & $10,7 \%$ \\
\hline & Jumlah & 65 & $100 \%$ \\
\hline
\end{tabular}

Berdasarkan tabel distribusi frekuensi Prestasi Belajar di atas dapat digambarkan dengan histrogram sebagai berikut:

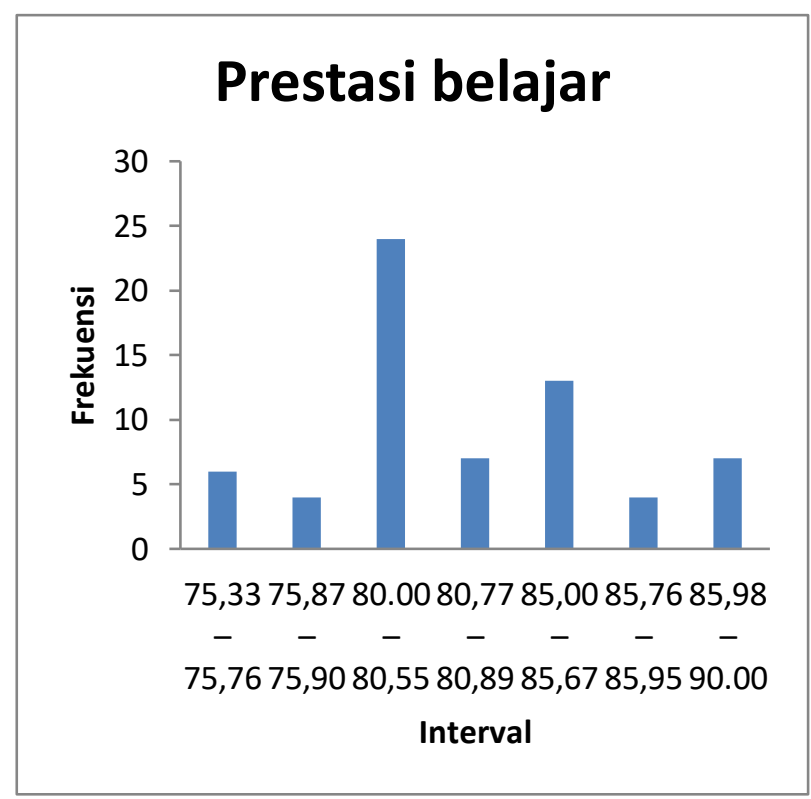
Variabel Prestasi Belajar 


$$
\begin{aligned}
& =\frac{1}{6}(90.00-75.33) \\
& =2.4 \\
& \text { Rendah }=<(\mathrm{Mi}-1 . \mathrm{SDi}) \\
& =<(82,6-2,4) \\
& =<80,2
\end{aligned}
$$

\begin{tabular}{|c|c|c|c|c|c|}
\hline No & $\begin{array}{c}\text { Kecend } \\
\text { erunga } \\
\mathbf{n}\end{array}$ & Skor & $\begin{array}{c}\text { Freku } \\
\text { ensi }\end{array}$ & $\begin{array}{c}\text { Presen } \\
\text { tase }\end{array}$ & Kategori \\
\hline 1 & $\begin{array}{c}<(\mathrm{Mi} \\
-1 \\
\mathrm{SDi})\end{array}$ & $\begin{array}{c}< \\
2,4\end{array}$ & 10 & $15,3 \%$ & Rendah \\
\hline 2 & $\begin{array}{c}(\mathrm{Mi}- \\
1 . \mathrm{SDi}) \\
\text { sampai } \\
(\mathrm{Mi}+ \\
\text { 1.SDi) }\end{array}$ & $\begin{array}{r}80,2 \\
-85\end{array}$ & 32 & $49,2 \%$ & Sedang \\
\hline 3 & $\begin{array}{c}>\text { (Mi } \\
+ \\
\text { 1.SDi) }\end{array}$ & $>85$ & 23 & $35,3 \%$ & Tinggi \\
\hline \multicolumn{2}{|c|}{ Jumlah } & & 65 & $100 \%$ & \\
\hline
\end{tabular}

Setelah diperoleh distribusi frekuensi dan dibuat histogram, selanjutnya di indentifikasi kecenderungan variabel prestasi belajar. Kecenderungan variabel presasi belajar diketahui dengan menghitung harga Mean ideal (Mi) dan Standar Deviasi ideal(Sdi). Berdasarkan data tersebut, diperoleh skor tertinggi 90.00 da skor terendah 75,33. Mean ideal (Mi) dan Standar Deviasi ideal (SDi) variabel prestasi belajar dihitung dengan rumus sebagai berikut:

Mean ideal $=\frac{1}{2}($ skor tertinggi + skor terendah $)$

$$
\begin{aligned}
& =\frac{1}{2}(90.00+75,33) \\
& =82,6
\end{aligned}
$$

Standar Deviasi $=\frac{1}{6}$ (skor tertinggi - skor terendah)
Sedang $\quad=(\mathrm{Mi}-1$. SDi $)-(\mathrm{Mi}+$ 1. SDi)

$$
=(82,6-2,4)-(82,6+
$$

$$
\begin{aligned}
& =80.2-85 \\
\text { Tinggi } & =>(\mathrm{Mi}+1 . \mathrm{SDi}) \\
& =>(82,6+2,4) \\
& =>85
\end{aligned}
$$

Berdasarkan perhitungan tersebut, maka diperoleh kecenderungan prestasi belajar, sebagai berikut:

Tabel 11.Kategori Frekuensi Kecenderungan prestasi belajar

Berdasarkan tabel diatas, variabel prestasi belajar menunjukkan terdapat 10 peserta didik (15,3\%) termasuk kategori Rendah, 32 peserta didik ( 49,2\%) termasuk kategori Sedang, dan 23 peserta didik $(35,3 \%)$ termasuk kedalam kategori Tinggi. Data tersebut menunjukkan kecenderungan prestasi belajar peserta didik kelas XI IPS Man 2 Pidie terletak pada kategori sedang. Berdasarkan tabel kategori frekuensi kecenderungan variabel 
prestasi diatas, maka dibuat pie chart distribusi frekuensi kecenderungan variabel prestasi yang disajikan dalam gambar berikut ini:

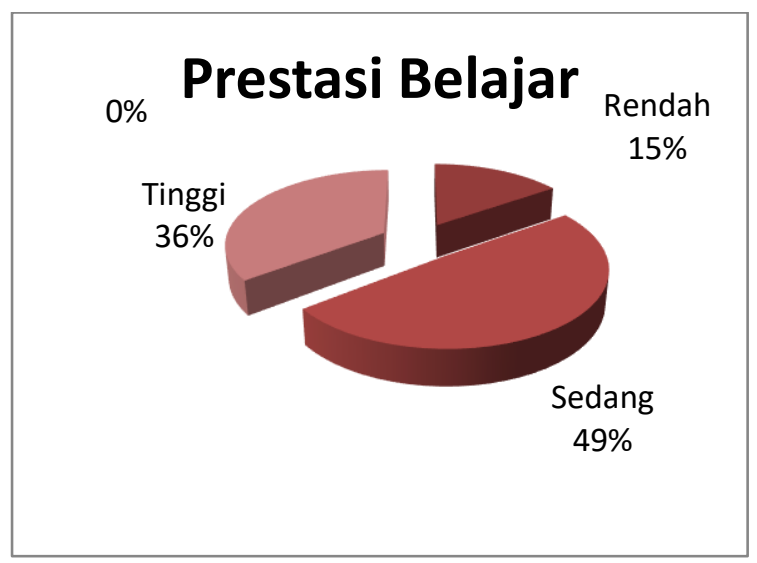

Gambar 6. Pie Chart Distribusi Frekuensi

KecenderunganVariabel Prestasi Belajar

\section{Uji Prasyarat Analisis}

\section{Uji Normalitas}

Uji normalitas bertujuan untuk mengetahui apakah data yang diperoleh dalam penelitian mempunyai distribusi normal atau tidak. untuk menguji normalitas digunakan uji Kolmogorov-smirnov dengan menggunakan IBM SPSS Statistics 20. Untuk menguji signifikan hasil perhitungan pada penelitian ini menggunakan taraf signifikan $5 \%(0.05)$.Jika nilai masing-masing variabel lebih besar dari 0,05 maka dapat disimpulkan bahwa variabel penelitian berdistribusi normal, dan sebaliknya jika di nilai variabel lebih kecil dari 0,05 maka variabel penelitian bersifat tidak normal. Setelah analisis dengan bantuan SPSS hasil masingmasing variabel penelitian akan dibuat dalam tabel berikut ini:

Tabel 12. Ringkasan Hasil Uji Normalitas

\begin{tabular}{|c|c|c|}
\hline \multirow{2}{*}{ Variabel } & Nilai & Signifik \\
\hline & Varia & an $(5 \%)$ \\
\hline
\end{tabular}

Perhatian Orang $\quad 0,379 \quad 0,05 \quad$ Normal Tua (X1)

$\begin{array}{cccc}\text { Motivasi (X2) } & 0,118 & 0,05 & \text { Normal } \\ \text { Prestasi Belajar } & 0,003 & 0,05 & \text { Normal }\end{array}$

Berdasarkan tabel diatas menunjukan bahwa ketiga variabel peneitian tersebut bersifat normal, berdasarkan uji Kolmogorov-Sirnov dan taraf signifikan $5 \%$ $(0,05)$.

\section{Uji Linieritas}

Tujuan uji linieritas untuk mengetahui apakah ada atau tidaknya hubungan antara masing-masing variabel bebas (X) dengan variabel terikat (Y). Uji linieritas dapat diketahui menggunakan harga koefisien $\mathrm{F}$ yang tercantum dalam ANOVA table dari output yang dihasilkan dengan bantuan SPSS. Taraf signifikan yang digunakan adalah $5 \%(0,05)$, jika Fhitung lebih besar dari Ftabel maka variabel terikat adalah linier.

Berdasarkan hasil uji Linieritas disimpulkan bahwa nilai Fhitung dari setiap variabel lebih kecil dari Ftabel dari signifikan 5 $\%$ (0,05). Jadi dapat disimpulkan bahwa semua variabel bebas terhadap variabel terikat memiliki hubungan yang linier.

\section{Pengujian Hipotesis}




\section{Uji Hipotesis Pertama}

Hipotesis pertama menyatakan bahwa "Ada hubungan positif antara perhatian orang tua dengan prestasi belajar siswa di MAN 2 pidie Kecamatan Mutiara. Hasil penghitungan hipotesis petama dengan IBMSPSS Statistics dapat dilihat dalam tabel dibawah ini:

Tabel 14. Ringkasan Hasil Analisis Korelasi Sederhana Hipotesis pertama

\begin{tabular}{|l|r|r|r|r|r|}
\hline Variabel & \multicolumn{2}{|c|}{ Harga r } & \multicolumn{2}{c|}{ Harga t } & Keterangan \\
\cline { 2 - 5 } & Hitung & Tabel & Hitung & Tabel & \\
\hline $\mathrm{Y} \rightarrow$ & 0,72 & 0,246 & 0,576 & 1,998 & $\begin{array}{r}\text { Positif dan } \\
\text { signifikan }\end{array}$ \\
& & & & & \\
\hline
\end{tabular}

Berdasarkan tabel diatas hasil analisis korelasi sederhana hipotesis pertama diatas diketahui nilai korelasi $\left(r_{x 1 y}\right)$ sebesar 0,72 Nilai $\left(r_{x 1 y}\right)$ berupa nilai positif, berarti bahwa perhatian orang tua memiliki hubungan positif dengan prestasi belajar. Selanjutnya, $r_{\text {hitung }}$ $\left(r_{x 1 y}\right)$ sebesar 0,72 lebih besar dari $r_{\text {tabel }}$ sebesar 0,246 menyatakan bahwa hipotesis yag berbunyi " Ada hubungan positif antara perhatian orang tua dengan prestasi belajar siswa di MAN 2 pidie Kecamatan Mutiara". Dinyatakan diterima.

Pengujian signifikasi bertujuan untuk mengetahui signifikansi hubungan antara perhatian orang tua dengan prestasi belajar. Setelah dilakukan uji $\mathrm{t}$ diperoleh nilai $t_{\text {hitung }}$ sebesar 0,576, apabila dibandingkan dengan nilai $t_{\text {tabel }}$ pada taraf signifikansi $5 \%$ dan $\mathrm{N}=$ 65 sebesar 1,998 maka $t_{\text {hitung }}>t_{\text {tabel }}(0,576>$ 1,998). Hal ini menunjukkan bahwa terdapat hubungan signifikan antara perhatian orang tua dan prestasi belajar siswa MAN 2 Pidie.

\section{Uji Hipotesis kedua}

Hipotesis kedua menyatakan bahwa “Ada hubungan positif antara motivasi dengan prestasi belajar siswa di MAN 2 pidie Kecamatan Mutiara. Hasil penghitungan hipotesis kedua dengan IBMSPSS Statistics 20

Berdasarkan hasil analisis korelasi sederhana hipotesis kedua diatas diketahui nilai korelasi $\left(r_{x 2 y}\right)$ sebesar 0,77 Nilai $\left(r_{x 2 y}\right)$ berupa nilai positif, berarti bahwa motivasi memiliki hubungan positif dengan prestasi belajar. Selanjutnya, $r_{\text {hitung }}\left(r_{x 2 y}\right)$ sebesar 0,77 lebih besar dari $r_{\text {tabel }}$ sebesar 0,246 menyatakan bahwa hipotesis yag berbunyi " Ada hubungan positif antara motivasi dengan prestasi belajar siswa di MAN 2 pidie Kecamatan Mutiara”. Dinyatakan diterima.

Pengujian signifikasi bertujuan untuk mengetahui signifikansi hubungan antara motivasi dengan prestasi belajar. Setelah dilakukan uji t diperoleh nilai $t_{\text {hitung }}$ sebesar 614 Apabila dibandingkan dengan nilai $t_{\text {tabel }}$ pada taraf signifikansi $5 \%$ dan $\mathrm{N}=65$ sebesar 1,998 maka $t_{\text {hitung }}<t_{\text {tabel }}(-614<1,998)$. Hal ini menunjukkan bahwa terdapat hubungan signifikan antara motivasi dengan prestasi belajar siswa MAN 2 Pidie. 


\section{Uji Hipotesis Ketiga}

Hipotesis ketiga menyatakan bahwa "Ada hubungan positif antara perhatian orang tua dan motivasi secara bersama-sama terhadap prestasi belajar siswa di MAN 2 Pidie Kecamatan Mutiara. Uji hipotesis ketiga dilakukan dengan analisis korelasi regresi ganda. Hasil penghitungan hipotesis ketiga dengan bantuan program IBM SPSS Statistics 20

Berdasakan hasil analisis analisis korelasi regresi ganda, diperoleh nilai koefisien korelasi $\left(R_{y(1,2)}\right)$ sebesar 0,112 Nilai $R_{y(1,2)}$ berupa nilai positif, berarti bahwa perhatian orang tua dan motivasi secara bersama-sama mempunyai hubungan positif dengan prestasi belajar siswa MAN 2 Pidie.

Pengujian signifikansi korelasi ganda dengan uji $\mathrm{F}$ ertujuan untuk mengetahui signifikan hubungan perhatian orang tua dan motivasi secara bersama-sama dengan prestasi belajar. Hasil perhitungan dengan bantuan IBM SPSS Statistics 20 menunjukkan Fhitung sebesar 3,92 dibandinggkan dengan Ftabel pada $\mathrm{db}=2 / 65$ dengan taraf signifikan 5\% diperoleh Ftabel sebesar 3,15 sehingga Fhitung > Ftabel yaitu 3,92 > 3,15. Hal ini menunjukkan bahwa terdapat hubungan signifikan antara perhatian orang tua dan motivasi secara bersama-sama dengan prestasi belajar siswa MAN 2 Pidie.

\section{Hubungan Antara Perhatian Orang Tua dengan Prestasi Belajar Siswa}

Hasil penelitian ini menunjukkan bahwa terdapat pengaruh positif Perhatian Orang Tua terhadap Prestasi Belajar. Melalui analisis regresi sederhana diperoleh harga koefisien korelasi $r_{x 1 y}=0,72$ yang menujukkan bahwa perhatian orang tua mempunyai hubungan positif dengan prestasi belajar siswa. Hasil penghitungan dengan uji $\mathrm{t}$ diperoleh $t_{\text {hitung }}$ 0,576 dan $t_{\text {tabel }}$ pada taraf signifikan 5\% sebesar 1,988 menunjukkan bahwa $t_{\text {hitung }}>t_{\text {tabel }}$ sehingga hubungan antara perhatian orang tua dengan prestasi belajar adalah signifikan.

Dari hasil analisis tersebut dapat digunakan untuk memprediksi bahwa semakin baik perhatian orang tua maka semakin tinggi pula prestasi belajar siswa. Dapat disimpulkan bahwa terdapat hubungan positif dan signifikan antara perhatian orang tua dengan prestasi belajar siswa kelas XI IIS MAN 2 Pidie tahun ajaran 2018, sehingga hipotesis pertama diterima.

Hal ini menunjukkan bahwa perhatian orang tua dapat mempengaruhi prestasi belajar siswa. Hal ini disebabkan dengan adanya perhatian orang tua maka siswa akan memiliki pemahaman diri sehingga mempunyai kepercayaan terhadap kemampuan sendiri serta memiliki pemahaman terhadap cara-cara belajar.

\section{Hubungan Antara Motivasi dengan Prestasi Belajar Siswa}


Hasil penelitian ini menunjukkan bahwa terdapat pengaruh positif motivasi terhadap Prestasi Belajar. Melalui analisis regresi sederhana diperoleh harga koefisien korelasi $r_{x 2 y}=0,77$ yang menujukkan bahwa motivasi mempunyai hubungan positif dengan prestasi belajar siswa. Hasil penghitungan dengan uji $\mathrm{t}$ diperoleh $t_{\text {hitung }} 614$ dan $t_{\text {tabel }}$ pada taraf signifikan $5 \%$ sebesar 1,988 menunjukkan bahwa $t_{\text {hitung }}>t_{\text {tabel }}$ sehingga hubungan antara motivasi dengan prestasi belajar adalah signifikan. Berdasarkan hasil yang diperoleh dapat disimpulkan bahwa motivasi belajar memberikan pengaruh positif dan signifikan terhadap prestasi belajar siswa kelas XI IPS MAN 2 Pidie tahun ajaran 2018, sehingga hipotesis kedua diterima.

Hasil tersebut menunjukkan bahwa semakin tinggi motivasi dalam belajar yang dimiliki peserta didik maka akan semakin tinggi prestasi belajar yang dicapai, sebaliknya semakin rendah motivasi dalam belajar yang dimiliki oleh siswa maka akan semakin rendah pula prestasi yang dicapai. Siswa yang memiliki motivasi dalam belajar yang baik maka ia akan mudah untuk melakukan kegiatan belajar dengan sendirinya sehingga siswa tersebut bisa mencapai hasil atau prestasi belajar yang baik

Hubungan Antara Perhatian Orang Tua dan Motivasi secara bersama-sama terhadap Prestasi Belajar Siswa.

Hasil penelitian hipotesis ke 3 menunjukkan bahwa ada hubungan positif dan signifikan antara perhatian orang tua dan motivasi secara bersama-sama terhadap prestasi belajar. Berdasarkan hasil perhitungan korelasi ganda, diperoleh nilai koefisien korelasi $R_{y(1,2)}$ sebesar 0.112 sehingga perhatian orang tua dan motivasi secara bersama-sama memiliki hubungan positif terhadap prestasi belajar. Setelah dilakukan uji $\mathrm{F}$ diperoleh $F_{\text {hitung }}$ sebesar 3,92 dan nilai $F_{\text {tabel }}$ pada taraf signifikan $5 \%$ sebesar 3,15. Hal ini menunjukkan bahwa $F_{\text {hitung }}>F_{\text {tabel }}$ sehingga perhatian orang tua dan motivasi secara bersama-sama terhadap prestasi belajar mempunyai hubungan yang signifikan. Berdasarkan hasil yang diperoleh dapat disimpulkan bahwa perhatian orang tua dan motivasi secara bersama-sama mempunyai hubungan positif dan signifikan terhadap prestasi belajar siswa kelas XI IIS MAN 2 Pidie tahun ajaran 2018, sehingga hipotesis ketiga diterima.

Berdasarkan hasil tersebut menunjukkan bahwa semakin tinggi perhatian orang tua dan motivasi dalam belajar yang dimiliki siswa maka akan semakin tinggi prestasi belajar yang dicapai, sebaliknya semakin rendah perhatian orang tua dan motivasi dalam belajar yang dimiliki siswa maka hasil prestasi yang dicapai juga akan rendah.

\section{SIMPULAN}

1. terdapat hubungan positif dan signifikan antara perhatian orang tua dengan prestasi belajar siswa IPS kelas XI MAN 2 Pidie 
Tahun ajaran 2018 yang ditunjukkan dengan nilai $r_{x 1 y}$ sebesar 0,72 dan $t_{\text {hitung }}$ lebih besar dari $t_{\text {tabel }}$ pada signifikan $5 \% \quad 0,576>$ 1,998. Hal ini berarti bahwa semakin baik perhatian orang tua maka akan semakin tinggi prestasi belajar yang dimiliki oleh siswa dan begitu pula sebaliknya.

2. terdapat hubungan positif dan signifikan antara motivasi dengan prestasi belajar siswa IPS kelas XI MAN 2 Pidie Tahun ajaran 2018 yang ditunjukkan dengan nilai $r_{x 2 y}$ sebesar0,77dan $t_{\text {hitung lebih besar dari }}$ $t_{\text {tabel }}$ pada signifikan 5\% 614> 1,998. Hal ini menunjukkan bahwa semakin tinggi motivasi dalam belajar yang dimiliki peserta didik maka akan semakin tinggi prestasi belajar yang dicapai, sebaliknya semakin rendah motivasi dalam belajar yang dimiliki oleh siswa maka akan semakin rendah pula prestasi yang dicapai. Siswa yang memiliki motivasi dalam belajar yang baik maka ia akan mudah untuk melakukan kegiatan belajar dengan sendirinya sehingga siswa tersebut bisa mencapai hasil atau prestasi belajar yang baik.

3. terdapat hubungan positif dan signifikan antara perhatian orang tua dan motivasi secara bersama-sama terhadap prestasi belajar siswa IPS kelas XI MAN 2 Pidie
Tahun ajaran 2018. Hal ini ditunjukkan dengan nilai $r_{y(1,2)}$ sebesar 0,112 dan $F_{\text {hitung }}$ lebih besar dari $F_{\text {tabel }}$ sebesar 3,92> 3,15 . Hal ini menunjukkan bahwa semakin tinggi perhatian orang tua dan motivasi dalam belajar yang dimiliki siswa maka akan semakin tinggi prestasi belajar yang dicapai, sebaliknya semakin rendah perhatian orang tua dan motivasi dalam belajar yang dimiliki siswa maka hasil prestasi yang dicapai juga akan rendah. 


\section{DAFTAR PUSTAKA}

Ahmadi, Abu dan Munawar. 2010. Psikologi Perkembangan, Jakarta: Rineka Cipta

Arikuto, Suharsimi.2006. Prosedur Penelitian Suatu Pendekatan Praktik, Jakarta: Rineka Cipta

Arifin. 2012. Evaluasi Pembelajaran. Bandung: PT Remaja Rosdakarya Offset.

Dakir. 1993. Dasar-Dasar Psikologi, Yogyakarta: Pustaka Pelajaran.

Hasbullah. 2013. Dasar-dasar Ilmu Pendidikan, Jakarta: PT RajaGrafindo Persada

Jaya. 2010. Statistik Penelitian Untuk Pendidikan, Bandung: Citapustaka Media Perintis.

Mardianto. 2012. Psikologi Pendidikan, Medan: Perdana Publishing

Margono,S.2005.Metodologi Penelitian Pendidikan.Jakarta: Rineka Cipta

Musthafa Fuhaim Syaikh. 2015. Kurikulum Pendidikan Anak Muslim, Surabaya: Pustaka eLBA

Rangkuti Ahmad Nizar.2014. Metode Peneliian Pendidikan. Bandung: Citapustaka Media

Ruswandi. 2013. Psikologi Pembelajaran, Bandung : CV.Cipta Pesona SejahteraSardiman. 2011. Interaksi \& Motivasi Belajar Mengajar, Jakarta: PT Raja Grafindo Persada.

Sardiman. 2011. Interaksi dan Motivasi Belajar Mengajar. Jakarta: Rajawali Press.

Sugiyono. 2013. Metode Penelitian Kuantitatif Kualitatif dan R\&D, Bandung: Alfabeta

Sukardi. 2013. Metodologi Penelitian Pendidikan, Jakarta: Bumi Aksara.

Sustrisno Hadi. 2004. Analisis Regresi, Yogyakarta: Andi Offset.

Walgito Bimo. 2002. Pengatar Psikologi Umum. Yogyakarta: Andi Offset. 